\title{
MENGEKSPLORASI KEARIFAN LOKAL: BERTINDAK LOKAL, BERPIKIR GLOBAL
}

\author{
Oleh: Ranto, S.IP., M.A
}

\section{A. Pendahuluan}

\section{Kearifan Lokal yang Tersisa}

Jika anda berpergian menuju wilayah Bangka Barat, jangan lupa berkunjung ke Desa Air Nyatoh, Kecamatan Simpang Teritip. Sebuah desa yang kaya potensi lautnya, seperti cumi kering, ikan labak, terasi, dan yang paling terkenal adalah ikan teri nasinya. Air Nyatoh juga lebih dikenal oleh masyarakat luas sebagai Desa Seribu Bagan, karena di desa ini sepanjang perairan lautnya beberapa kilometer terdapat lebih dari 200 bagan.

Selain hasil lautnya, desa ini juga dikenal sebagai salah satu daerah surga buah durian yang ada di Bangka Barat. Bahkan, ketika musim durian tiba, desa ini memiliki kebiasaan yang disebut oleh masyarakat lokal sebagai "ngedamber durin”. Desa ini sekaligus memiliki garis pantai yang panjang, cukup indah untuk dijadikan tempat istirahat bersama keluarga. Saya cukup sering berkunjung ke desa ini, sehingga nyaris hapal seluk beluk yang ada di desa Air Nyatoh.
Ketika kita mulai melewati rumah terakhir menuju kawasan pantai, terlihat pondok-pondok nelayan lokal berbaris yang memberikan kesan tertata rapi. Jika anda datang di pukul 06.00 pagi di musim melaut (bulan April-September) biasanya perahu nelayan mulai menepi membawa hasil tangkapannya setelah semalaman berada di bagan untuk mencari ikan, cumi dan lain sebagainya. Lalu lalang masyarakat lokal seperti tak ada hentinya untuk mengangkut hasil laut yang didapatkan, mulai dari pengepul lokal, hingga pembeli perseorangan dari berbagai desa yang ada disekitar Kabupaten Bangka Barat.

Namun, jika anda datang disiang hari, maka pemandangan di halamanhalaman depan, samping dan belakang dekat pondok-pondok nelayan berhamparan jenis ikan, cumi dan hasil laut lainnya yang telah direbus kemudian dijemur hingga kering.

Beberapa bulan yang lalu, tepatnya di hari Rabu minggu terakhir bulan Safar 2016, di Kecamatan Simpang Teritip di Desa Air Nyatoh, dilaksanakan upacara tradisional (adat) Rebu Kasan. Perayaan 
Rebu Kasan ini dimaknai oleh masyarakat setempat sebagai wujud syukur atas berlimpahnya hasil laut yang memang dilakukan secara turun temurun. Selain ungkapan rasa syukur, Rebu Kasan sekaligus juga menjadi ritual doa untuk meminta kepada sang pencipta agar hasil tangkapan ikan di tahun mendatang semakin berlimpah.

Pelaksanaan Rebu Kasan ini selalu dikaitkan dengan pentingnya peran laut bagi masyarakat setempat dalam memenuhi kebutuhan kesehariannya. Oleh karenanya, satu pesan penting yang disampaikan oleh tradisi Rebu Kasan ini adalah: menjaga ekologi laut. Tak mengejutkan jika masyarakat di Desa Air Nyatoh ini menolak keras kehadiran aktifitas pertambangan timah di laut. Hal ini penting karena masyarakat di Air Nyatoh tidak ingin termarginalkan oleh aktifitas pertambangan laut yang merugikan secara material bagi nelayan lokal di masa mendatang.

Sederhananya, jika sistem ekologi di laut rusak oleh aktifitas pertambangan maka tradisi Rebu Kasan sudah tidak memiliki makna apapun. Seperti yang telah disebutkan dibagian paling awal, perayaan Rebu Kasan sebagi bentuk suka cita karena laut telah memberikan hasilnya yang berlimpah bagi masyarakat setempat untuk memenuhi kebutuhan hidupnya sehari-hari.

\section{B. Pembahasan}

\section{Kearifan Lokal sebagai Penyelaras Kehidupan}

Banyak pihak meyakini bahwa kearifan lokal atau yang populer disebut dengan local wisdom menjadi petunjuk yang bijaksana dalam menyeimbangkan kehidupan sosial di masyarakat lokal. Mengutip Edi Santoso menyebutkan bahwa kearifan lokal dipahami secara umum sebagai gagasan-gagasan yang sangat lokalitas yang bernilai baik, penuh kearifan sekaligus bersifat bijaksana yang melekat, diyakini dan ditaati oleh masyarakat setempat. Masih menurut Edi Santoso, dalam sebuah kearifan lokal itu mengandung kearifan budaya lokal yang diartikan sebagai bagian dari pengetahuan lokal yang bersatu dengan nilai-nilai kepercayaan, budaya, norma yang diaktualisasikan dalam tradisi dan mitos dalam jangka waktu berkepanjangan.

Dalam sebuah kesempatan, Francis Wahyono (2005)—-seperti dikutip oleh Edi Santoso-menyebutkan bahwa kearifan lokal itu merupakan wujud kepandaian dalam membuat dan menjalankan strategistrategi pengelolaan alam semesta untuk 
menjaga kesimbangan ekologis yang diakibatkan oleh kelalaian manusia. Tak hanya itu, kearifan lokal tidak hanya berhenti pada etika, lanjut Francis Wahyono, kearifan lokal dapat menjadi religi (kepercayaan)tetapi sampai pada norma, tingkah laku dan tindakan keseharian maupun penentuan peradaban masa depan.

Oleh karenanya, kembali pada konteks tradisi Rebu Kasan di Desa Air Nyatoh merupakan pengejewantahaan makna untuk melestarikan ekosistem di laut. Jika kita telusur bentuk eksploitasi sumber daya yang ada di laut yang dilakukan oleh masyarakat nelayan di Air Nyatoh masih mempertahankan proses yang tradisional. Misalnya, nelayan di sana dilarang keras melakukan aktifitas pengeboman di laut untuk menangkap ikan. Selain itu, masyarakat yang menggantungkan hidupnya dari hasil laut juga tidak diperkenankan menggunakan alat tangkap yang dapat merusak terumbu karang dan biota laut lainnya. Tentu saja, fenomena demikian menegaskan kepada kita bahwa pola-pola alat produksi yang digunakan masyarakat setempat untuk mengeksploitasi hasil laut seperti mencari ikan misalnya masih mempertimbangkan dan mementingkan kelestarian ekosistem di laut. Kondisi demikian tentu berbeda dengan masyarakat di perairan lainnya seperti di Dusun Selindung, Desa Air Putih, Kecamatan Muntok yang tidak gigih manjaga kelestarian lautnya.

Tidak ada yang bisa membayangkan jika masyarakat Air Nyatoh yang mayoritas penduduknya berprofesi sebagai nelayan lebih memilih cara hidup pragmatis dalam mengeksploitasi lautnya untuk kepentingan jangka pendek dengan menukarkan kepentingan jangka panjang. Tak mengherankan di sebuah desa yang menamakan dirinya dengan sebutan BALER (Bersih Aman Lestari Elok dan Rapi) ini masyarakatnya masih memegang teguh tradisi kelautan dengan melekatkan pada kebudayaan maritim. Di desa ini, kita kesulitan menemukan lubang-lubang penggalian timah.

\section{Berkah dari Kepandaian Menjaga Kearifan Lokal}

Desa yang telah ditetapkan oleh Pemerintah Daerah Kabupaten Bangka Barat sebagai Desa Mandiri Tahap II Tahun 2014 ini memang terkenal dengan nelayan bagannya. Hampir setengah dari kepala keluarga di Air Nyatoh memiliki bagan sebagai sarana mata pencahariannya. Berdasarkan pengakuan tokoh masyarakat setempat, yakni Arso menyebutkan bahwa di bulan April sampai September setiap 
bagan bisa memperoleh lima belas sampai dua puluh kilogram Teri Nasi dalam sekali operasional.

Pengakuan lainnya juga disampaikan oleh Rosmawati yang menyampaikan bahwa setiap hari usaha yang dilakukannya rata-rata mengelolah berbagai jenis ikan menjadi ikan asin sekitar 800 kilogram. Bahkan, sewaktu musim ikan teri tiba bisa menghasilkan dua ton per hari. Berbagai olahan ikan yang didapat masih diproses secara tradisional dan alami tanpa pengawet atau bahan kimia berbahaya.

Berdasarkan catatan statistik Kabupaten Bangka Barat angka produksi perikanan lautnya pada tahun 2014 mencapai 12.653,08 Ton dengan nilai mencapai Rp. 433,57milyar, yang mana sejumlah 2.511,50 Ton yang bernilai Rp. 70,98 milyar disumbangkan dari Kecamatan Simpang Teritip. angka ini merupakan rekor tertinggi jika dibandingkan dengan kecamatan lainnya yang ada di Bangka Barat.

Cerita-cerita yang telah disebutkan menunjukkan bahwa jika kita piawai dalam mengelola kehidupan yang selaras dan harmoni dengan lingkungan maka keuntungan ekonomis kemudian selalu mengikuti. Tak mengherankan, jika masyarakat Air Nyatoh tidak terlalu tergoda untuk mencari pekerjaan lain di daerah yang lainnya selain kegiatan yang berhubungan dengan laut dalam memenuhi kebutuhan sehari-harinya.

\section{Dari Kampung Menuju Pentas Dunia: Mungkinkah?}

Selama ini hasil tangkapan laut yang diperoleh dari aktifitas menggunakan jaring atau pukat, dan perangkap bagan yang dimiliki oleh nelayan lokal. Meskipun dengan cara yang cukup sederhana, perolehan hasil tangkapan ikan masyarakat Air Nyatoh mampu memenuhi kebutuhan masyarakat di Bangka Belitung. Bahkan, ikan teri nasi yang identik dengan daerah ini diminati oleh masyarakat di luar Bangka Belitung seperti Palembang. Hanya saja, produk yang dioleh dari hasil tangkapan laut di desa ini masih belum variatif.

Padahal, jika dicermati kondisi kekinian, perolehan hasil tangkapan nelayan yang telah dioleh dalam bentuk makanan seperti kerupuk, getas, kemplang, cumi kering, ikan asin, rusip dan terasi sangat diminati oleh pebisnis internasional. Menurut Sarjulianto, produk olahan ikan yang dihasilkan masyarakat di Bangka Belitung diminati oleh masyarakat Eropa, Afrika, dan Asia karena memiliki cita rasa yang khas dan berkualitas tinggi. Masih menurutnya, pernah pihak pemerintah 
daerah menolak kerjasama dengan pengusaha asal Yaman untuk mengekspor hasil olahan laut dengan minimal produksi satu ton perbulan karena tidak bisa menjamin dapat memenuhi permintaan tersebut.

Padahal, di tahun 2014, produksi pengolahan hasil perikanan di Bangka Belitung mencapai 73,103 Ton. Hasil yang dihasilkan dengan sejumlah ini ternyata hanya cukup untuk memenuhi konsumsi masyarakat lokal dan sekitarnya saja. Melihat kondisi demikian, rencana kerjasama dengan pengusaha dari Yaman tadi terpaksa dibatalkan mengingat pegiat olehan makanan ikan di Bangka Belitung belum mampu memproduksi jumlah yang diingankan oleh pihak investor tadi.

\section{Penutup}

Selama ini kita terlalu mengabaikan potensi-potensi nilai kearifan lokal yang ada untuk dijadikan kekuatan bagi peningkatan kualitas kehidupan masyarakat. Padahal, nilai kearifan lokal yang selama ini melalang buana dalam keseharian belum kita anggap sebagai hal yang penting, tak saja penting bagi memenuhi kebutuhan-kebutuhan sehari-hari, ternyata juga sangat menentukan arah peradaban kemanusiaan di masa mendatang.

\section{Refrensi:}

Edi Santoso yang bertemakan: "Revitalisasi dan Eksplorasi Kearifan Lokal (Local Wisdom) dalam Konteks Pembangunan Karakter Bangsa" tahun terbit dan nama jurnal penerbitnya belum berhasil saya ketahui.

https://m.tempo.co/read/news/2015/10/1 0/090708266/perajin-ukm-babel-kewalahanpenuhi-ekspor-produk-olahan-ikan. Diakses pada 18 Oktober 2016, jam 12.30 wib

Tabloid Sejiran Setason, "Desa Seribu Bagan” dalam Vol. VIII Edisi 1 Tahun 2015

Badan Pusat Statistik Kabupaten Bangka Barat, Bangka Barat Dalam Angka 2014, Tahun 2014

Dinas Kebudayaan Pariwisata Pemerintah Provinsi Kepulauan Bangka Belitung, Upacara Adat Bangka Belitung, 2015 